\title{
Ekonomi Islam Sebagai Solusi Krisis Ekonomi
}

\author{
Rifki Syuja' Hilman \\ Pondok Pesantren Bismillah, Tangerang, Banten \\ E-mail: aiqibizmi@gmail.com
}

\begin{abstract}
The economic crisis in perceptive Islam is inseparable from economic practices that are contrary to Islamic values, such as usury (monopoly), corruption, and other malpractices. But the common mistake made in identifying the root of the crisis that occurred only limited to the search on the symptom (symptoms). As a result, healing is only temporary, like analgesic drugs, temporarily relieving pain. At the Moments later, the crisis reappeared, even deeper and more serious. This paper tries to uncover some of the causes of the economic crisis, along with the solutions offered by Islamic economics as an effort to solve the crisis that has occurred.
\end{abstract}

Keywords: Islamic economy, economic crisis, gold and silver, zakah.

\section{Pendahuluan}

Pengalaman krisis demi krisis yang menimpa ekonomi dunia dalam satu abad terakhir ini seharusnya telah menyadarkan kepada kita bahwa bobroknya ekonomi telah menjalar menjadi persoalan yang semakin kompleks. Diawali dengan terjadinya malapetaka yang besar (great depressions) pada tahun 1930-an ${ }^{1}$, kemudian disusul dengan terjadinya krisis di Amerika Latin pada dekade 1970$\mathrm{an}^{2}$, akhirnya muncul kembali pada krisis moneter di Asia pada pertengahan tahun

\footnotetext{
${ }^{1}$ Krisis ini terjadi selama 10 tahun yaitu tahun 1929-1939, krisis ini merupakan yang terbesar sepanjang sejarah, akibat kegagalan pasar waktu itu. Upaya yang dilakukan untuk mengatasi adalah dengan konsep keynesianisme yang diadaptasi oleh Presiden Amerika Serikat yaitu Rosevelt melalui kebijakan new deal dimana negara ikut berperan dalam mengatur pelaksanaan regulasi pasar dan memberikan stimulus ekonomi.

${ }^{2}$ Krisis tahun 1970-an: Terjadi akibat kesepakatan perjanjian Breton Wood runtuh (collapsed) oleh Presiden Nixon, kesulitan ekonomi yang diakibatkan perang Vietnam dan embargo minyak. Pada hakikatnya perjanjian Bretton Wood ini runtuh akibat sistem dengan mekanisme bunganya yang tak dapat dibendung, demi tetap mempertahankan rezim nilai tukar yang fixed exchange rate. Selanjutnya pada tahun 1971-1973 terjadi kesepakatan Smithsonian (di mana saat itu nilai 1 Ons emas = 38 USD). Pada fase ini dicoba untuk menenangkan kembali sektor keuangan dengan perjanjian baru. Namun hanya bertahan 2-3 tahun saja.
} 
1997-an ${ }^{3}$, dan yang terbaru krisis muncul dari negara adidaya Amerika Serikat tahun 2008 yang memicu krisis keuangan di seluruh penjuru dunia ${ }^{4}$. Oleh beberapa ekonom dunia, hal ini disinyalir terjadi karena bobroknya sistem ekonomi kapitalis yang mereka agung-agungkan. ${ }^{5}$ Para ekonom sibuk mencari jalan keluar untuk menyelesaikan krisis tersebut, sekarang mereka sedang melirik sistem ekonomi Islam karena beberapa bukti telah menunjukkan keistimewaannya. Hal ini terbukti sebagaimana diungkapkan dalam surat kabar Republika $^{6}$, bahwasanya saat krisis mengguncang perekonomian Amerika Serikat sejumlah pakar Departemen Keuangan negara adidaya tersebut mempelajari berbagai fitur penting perbankan syari'ah. Saat itu pemerintah AS memandang perlu membahas efektifitas sistem perbankan syari'ah dalam kondisi krisis keuangan global.

Di Sudan, sebagai salah satu negara Islam yang mengadopsi sistem ekonomi Islam juga telah membuktikan bahwa tingkat inflasi telah menurun drastis dari lebih $100 \%$ sebelum ekonominya dilaksanakan secara Islami ke 3\% pada tahun 1993 dibawah sistem ekonomi Islam ${ }^{7}$. Inilah kelebihan ekonomi Islam yang mengagumkan yang tidak akan pernah kita dapati dalam sistem ekonomi ribawi. ${ }^{8}$ Hal diatas membuktikan akan kehebatan ekonomi Islam, salah satu karakteristiknya adalah peniadaan bunga dalam setiap kegiatan perekonomiannya agar masyarakat tidak ada yang terdzolimi serta mengedepankan kemaslahatan masyarakat secara luas. Keistimewaan ini seharusnya diketahui secara mendalam oleh umat Islam sendiri, hal ini ditujukan agar mereka bisa mendukung perekonomian Islam baik dengan jalan menginvestasikan uangnya kedalam perbankan syari'ah ataupun bantuan moril lainnya. Apabila umat Islam sudah melakukan hal ini, bukan hal yang mustahil sistem ekonomi Islam akan menjadi sistem ekonomi dunia.

\footnotetext{
${ }^{3}$ Krisis Finansial Asia 1997 Bermula di Thailand dan mempengaruhi mata uang, bursa saham dan harga aset lainnya di beberapa negara Asia, sebagian Macan Asia Timur seperti Korea, Indonesia, Malaysia dan sebagainya. Dalam menganalisa penyebab utama timbulnya krisis moneter tersebut, banyak para pakar ekonomi berkonklusi bahwa kerapuhan fundamental ekonomi (fundamental economic fragility) dan kebijakan hutang yang tidak transparan adalah merupakan penyebab utama munculnya krisis ekonomi.

${ }^{4}$ Pinjaman subprime mortgage (kredit perumahan) oleh beberapa bank ditengarai menjadi penyebab terjadinya krisis di Amerika Serikat, alhasil krisis tersebut pun meluas dan menjadi pemicu krisis keuangan yang lebih lebar mencakup pasar modal dan perbankan. Walaupun pemerinatah Amerika Serikat telah memberi dana talangan (bailout) sebesar 700 miliar dolar, ternyata dana talangan ini belum dianggap cukup untuk menyelesaikan krisis tersebut.

5 Aam Slamet Rusdianta dkk, Ekonomi Islam Substantif, (Bogor: Lembaga Penelitian dan Pemberdayaan Masyarakat (LPPM) STIE Tazkia 2009), hal 46.

6 "Bank di Amerika terapkan Prinsip Syari'ah", harian Republika, tanggal 19 Juni 2010, hal 20

7 Shabri Abdul Madjid [alumni Bidang Ekonomi pada International Islamic University, Malaysia (IIUM). Sumber: http://www.bmtlink.web.id/Wacana180502.htm.

${ }^{8}$ Bukti lain datang dari Inggris, dimana tahun 2008 Bank Syari'ah Inggris, Islamic Bank of Britan (IBB) kedatangan sejumlah besar nasabah non--muslim. Dengan adanya nasabah baru terasebut IBB melaporkan terjadinya kenaikan jumlah nasabah sebanyak 5\% dan $13 \%$ pada tabungan nasabah.
} 
Berdasarkan pemaparan diatas, makalah ini mencoba untuk menguraikan akan keistimewaan ekonomi Islam dalam memecahkan masalah krisis dengan judul "Ekonomi Islam Solusi Krisis Ekonomi: Tinjauan Teoritis" dengan harapan makalah ini akan memberikan motivasi dan semangat penulis dan pembaca selaku umat Islam agar lebih mendukung perekonomian syari'ah baik bantuan moril maupun materil.

\section{Ekonomi Islam: Definisi, Karakteristik dan Kebijakannya}

Ekonomi merupakan bagian integral dari ajaran Islam, dan karenanya ekonomi Islam akan terwujud hanya jika ajaran Islam diyakini dan dilaksanakan secara menyeluruh. Ekonomi Islam mempelajari perilaku ekonomi individu-individu yang secara sadar dituntun oleh ajaran Islam Al-Qur'an dan Sunnah dalam memecahkan masalah ekonomi yang dihadapi. Berbagai ahli ekonom muslim memberikan definisi ekonomi Islam yang bervariasi, diantaranya ada yang mengungkapkan bahwa Ekonomi Islam adalah kumpulan dari dasar-dasar umum ekonomi yang diambil dari Al-Qur'an dan Sunnah Rasulullah serta dari tatanan ekonomi yang dibangun atas dasar-dasar tersebut sesuai dengan berbagai macam bi 'ah (lingkungan) dan setiap zaman. ${ }^{9}$ Adapula yang mendefinisikan bahwasanya ekonomi Islam adalah ilmu yang mempelajari usaha-usaha manusia untuk mengalokasikan dan mengelola sumber daya untuk mencapai falah berdasarkan pada prinsip dan nilai-nilai Al-Qur'an dan Sunnah. ${ }^{10}$ Di sisi lain, Umer Chapra mendefinisikan ekonomi Islam sebagai berikut, ${ }^{11}$

"Ekonomi Islam adalah cabang pengetahuan yang membantu merealisasikan kesejahteraan manusia melalui alokasi distribusi sumber-sumber daya yang langka yang seirama dengan asset, tanpa mengekang kebebasan individu, menciptakan keseimbangan makroekonomi dan ekologi yang berkepanjangan, atau melemahkan solidaritas keluarga dan sosial serta jaringan moral masyarakat".

Jadi Ekonomi Islam hadir bukan hanya sebagai wujud ekspresi syari'ah yang memberikan eksistensi Islam ditengah-tengah eksistensi berbagai sistem ekonomi modern. Tapi sistem ekonomi Islam lebih sebagai pandangan agama Islam yang kompleks dan merupakan hasil ekspresi akidah Islam dengan nuansa yang luas dan target yang jelas. ${ }^{12}$ Adapaun tujuan-tujuan ekonomi Islam itu didasarkan pada

\footnotetext{
${ }^{9}$ Ahmad Izzan dan Syahri Tanjung, "Referensi Ekonomi Syari'ah (ayat-ayat al-qur'an yang berdimensi ekonomi), (Bandung: PT. Remaja Rosdakarya, 2006), hal. 32.

10 Pusat Pengakjian dan Pengembangan Ekonomi Islam, Ekonomi Islam, (Jakarta: PT. Rajagrafindo, 2008), hal, 19.

${ }^{11}$ Ismail Nawawi, Ekonomi Islam, Perspektif Teori, Sistem dan Aspek Hukum, (Surabaya: CV. Putra Media Nusantara), hal 7.

${ }^{12}$ M. Faruq an-Nababan, Sistem Ekonomi Islam (pilihan setelah kegagalan sistem kapitalis dan sosialis), (UII Press: Jogjakarta, 2002), hal vii.
} 
konsep-konsepnya sendiri mengenai kesejahteraan manusia (maslahah) ${ }^{13}$, kebahagiaan dunia dan akhirat (falah), dan kehidupan yang baik (hayat thayyibah). Sebagaimana yang diungkapkan al-Ghazali bahwasanya yang termasuk dalam tujuan-tujuan syari'ah (Maqashidu Syari'ah) adalah segala sesuatu yang perlu dipenuhi untuk melindungi dan memperkaya iman, kehidupan, akal, keturunan dan harta benda. ${ }^{14}$ Tujuan ini dilandasi oleh beberapa hal penting sebagai asumsi dasar ekonomi Islam, sebagai berikut: ${ }^{15}$ (a) mengakui hak milik (baik secara individu maupun umum); dalam hal ini ekonomi Islam memadukan antara maslahah individu dan maslahah umum. Nampaknya inilah satu-satunya jalan untuk mencapai keseimbangan dan keadilan di masyarakat. (b) kebebasan ekonomi bersyarat; Islam memberikan kebebasan bagi setiap individu untuk memiliki, memproduksi, mengkonsumsi, berjual beli dan sebagainya, tetapi dengan syarat tidak bertentangan dengan kepentingan umum. (c) kebersamaan dalam menanggung suatu kebaikan (at-Takaful Al-Ijtima’i); dalam kerangkan ekonomi Islam adalah kebersamaan yang timbal balik antar sesama anggota masyarakat dengan pemerintahan baik dalam kondisi lapang maupun sempit untuk mewujudkan kesejahteraan atau dalam mengantisispasi suatu bahaya. Selanjutnya, karakteristik Ekonomi Islam adalah sebagai berikut: ${ }^{16}$

a) Ekonomi Islam merupakan bagian yang tak terpisahkan dari konsep Islam yang utuh dan menyeluruh,

b) Aktivitas ekonomi Islam merupakan suatu bentuk ibadah,

c) Tatanan ekonomi Islam memiliki tujuan yang sangat mulia,

d) Ekonomi Islam merupakan sistem yang memiliki pengawasan melekat yang berakar dari keimanan dan tanggung jawab kepada Allah,

e) Ekonomi Islam merupakan sistem yang menyelaraskan antara maslahah individu dan maslahah umum. ${ }^{17}$

Berdasarkan tujuan ekonomi Islam yakni mencapai falah, hal ini akan terwujud apabila kebijakannya mendukung; yang dimaksud dengan kebijakan disini adalah segala sesuatu yang akan menjadi persyaratan bagi implementasi ekonomi Islam, sebagai suatu keharusan. Sebagai sebuah basis, maka eksistensi hal-hal dibawah ini mutlak harus diusahakan, sebab jika tidak maka akan

13 Maslahah adalah segala bentuk keadaan ataupun perilaku yang mampu meningkatkan kedudukan manusia sebagai makhluk yang paling mulia. Terdapat lima maslahah mendasar yang diperlukan oleh manusia, yaitu maslahah fisik, maslahah intelektual, maslahah antergenerasi dan waktu, maslahah agama, dan maslahah materi/ kekayaan.

14 Umer Chapra, Islam dan Tantangan Ekonomi, (Surabaya: Risalah Gusti, 1999), hal, 8.

15 Konsep Takaful ini bisa dijabarkan lebih lanjut menjadi beberapa hal yaitu: (1) jaminan terhadap pemilikan dan pengelolaan sumber daya oleh individu, (2) jaminan setiap individu untuk menikmati hasil pembangunan atau output, (3) jaminan setiap individu untuk membangun keluarga sakinah, (4) jaminan untuk amar ma'ruf nahi munkar.

${ }^{16}$ Pusat Pengakjian dan Pengembangan Ekonomi Islam,.. hal 54

${ }^{17}$ Dalil mengenai hal ini dapat dilihat dalam (QS Al-Baqarah[2]: 188), dan (An-Nisa'[4]: 29, 161 dan (At-Taubah: 34). 
mengganggu optimalisasi dan efektivitas implementasi ekonomi Islam. Kebijakan ini adalah sebagai berikut:

a) Penghapusan Riba

Islam telah melarang segala bentuk riba karenanya ia harus dihapuskan dalam ekonomi Islam. ${ }^{18}$ Pelarangan riba secara tegas ini dapat dijumpai dalam Alqur'an ${ }^{19}$ dan Hadits. Salah satunya buktinya adalah sebagai berikut:

"Orang-orang yang makan (mengambil) riba tidak dapat berdiri melainkan seperti berdirinya orang yang kemasukan syaitan lantaran (tekanan) penyakit gila. keadaan mereka yang demikian itu, adalah disebabkan mereka Berkata (berpendapat), Sesungguhnya jual beli itu sama dengan riba, padahal Allah Telah menghalalkan jual beli dan mengharamkan riba. orang-orang yang Telah sampai kepadanya larangan dari Tuhannya, lalu terus berhenti (dari mengambil riba), Maka baginya apa yang Telah diambilnya dahulu (sebelum datang larangan); dan urusannya (terserah) kepada Allah. orang yang kembali (mengambil riba), Maka orang itu adalah penghuni-penghuni neraka; mereka kekal di dalamnya.

Esensi dari penghapusan riba adalah penghapusan ketidakadilan dan penegakan keadilan dalam ekonomi. ${ }^{20}$

b) Pelembagaan zakat

Sebagaimana diketahui zakat adalah uang iuran (levy) yang diwajibkan atas harta seorang muslim yang telah memenuhi syarat, bahkan ia merupakan rukun Islam yang ketiga. Zakat pada dasarnya merupakan suatu sistem yang berfungsi untuk menjamin distribusi pendapatan dan kekayaan masyarakat secara lebih baik. Karena zakat adalah poros dan pusat keuangan negara Islami, ${ }^{21}$ karena zakat meliputi bidang moral, sosial dan ekonomi ${ }^{22}$.

\footnotetext{
18 Umer Chapra, Al-Qur'a Menuju Sistem Moneter yang Adil, Cet. 1, (Yogyakarta: Dana Bhakti Prima Yasa, 1997), hal 27.

19 Pelarangan riba dalam Al-Qur'an antara lain telah termaktub dalam QS Ar-Rum: 39, QS An-Nisa: 161, QS Ali Imran: 130-132 dan QS Al-Baqarah[2]: 275-281.

20 Argumentasi rasional tentang alasan-alasan pelarangan riba dalam perekonomian secara komperhensif bisa dilihat dalam Afzalur Rahman, Economic Doctrines in Islam terj. Doktrin Ekonomi Islam, (Yogyakarta: Dana Bhakti Wakaf), 1995, hal 13-225.

21 M. Abdul Mannan, Teori dan Praktek Ekonomi Islam, (Yogyakarta: PT Dana Bhakti Prima Yasa), 1997, hal 256.

22 Dalam bidang moral, zakat mengikis habis ketamakan dan keserakahan si kaya. Dalam bidang sosial, zakat bertindak sebagai alat khas yang diberikan Islam untuk menghapuskan kemiskinan dari masyarakat dengan menyadarkan si kaya akan tanggung jawab sosial yang mereka miliki. Dalam bidang ekonomi, zakat mencegah penumpukan kekayaan yang mengerikan dalam tangan segelintir orang dan memungkinkan kekayaan untuk disebarkan sebelum sempat menjadi besar dan sangat berbahaya di tangan para pemilikinya.
} 
Ia akan menjadi sebuah sistem yang akan menjaga keseimbangan dan harmoni sosial diantara kelompok kaya (muzakki) dan kelompok miskin (mustahik).

c) Pelarangan Gharar

Ajaran Islam melarang aktivitas ekonomi yang mengandung gharar. Dari segi bahasa, gharar berarti resiko, atau juga ketidakpastian. Menurut Ibnu Taimiyah gharar adalah sesuat dengan karakter yang tidak diketahui sehingga menjual hal ini adalah seperti perjudian. Dengan kata lain, gharar terjadi karena seseorang sama sekali tidak dapat mengetahui kemungkinan kejadian sesuatu sehingga bersifat spekulatif. Selain itu juga dalam gharar terkandung pengertian, sebagaimana game theory, apa yang disebut zero sum game with uncertainty pay-off -yang artinya jika satu pihak menerima keuntungan, maka pihak lain pasti mengalami kerugian.

\section{Krisis Ekonomi: Definisi dan Faktor Penyebabnya}

Krisis pada pinjaman subprime mortgage di Amerika serikat pada pertengahan 2007, menyentak kesadaran kita semua akan akibatnya yang menjalar ke seluruh penjuru dunia. Pada awal 2008, krisis tersebut meluas dan menjadi pemicu krisis keuangan yang lebih luas mencakup pasar modal dan perbankan. Indonesiapun tak bisa memungkiri krisis ini, dan menjadi salah satu negara yang terkena imbasnya. Dimana indeks harga saham gabungan (IHSG) di Bursa Efek Indonesia (BEI) jatuh secara beruntun, dan akhirnya ditutup selama 3 hari guna mencegah kekacauan dan kejatuhan yang lebih besar. ${ }^{23}$

Krisis ekonomi secara umum didefinisikan sebagai jatuhnya nilai mata uang domestik terhadap mata uang asing utama dalam hal ini biasanya adalah US dolar, yang dibarengi dengan meningkatnya tingkat harga secara keseluruhan. ${ }^{24}$ Sementara Kaminsky, Lizondo dan Reinhart (KLR) mengombinasikan informasi atas naiknya tingkat bunga, turunnya cadangan devisa dan depresiasi mata uang yang besar ke dalam suatu indeks sebagai gejala terjadinya krisis. Sedangkan Bank Dunia mendefinisikan krisis keuangan bila indeks krisis melebihi 1,5 kali dari standar deviasi terhadap rata-rata. Dalam penelitian ini, indeks krisis hanya menggunakan indikator nilai tukar rupiah terhadap US dolar dengan batas 2 kali standar deviasi diatas rata-rata. Dari dua definisi ini dapat diambil kesimpulan bahwasanya krisis ekonomi terjadi ketika nilai mata uang domestik jatuh yang dibarengi dengan naiknya semua harga yang ada dipasaran.

23 Dr. Muhammad Handry Imansyah, Krisis Keuangan di Indonesia Dapatkah Diramalkan?, (Jakarta: PT Elex Media Komputindo), 2009, hal xxi

24 Ibid, hal 60 
Beberapa pendapat menyatakan penyebab terjadinya krisis ekonomi, salah satunya dari Zulhelmy yang mengungkapkan empat faktor utama penyebab krisis: ${ }^{25}$

a) Tersingkirnya Emas Sebagai Cadangan Mata Uang

Dengan disingkirkannya emas sebagai cadangan mata uang dan dimasukkannya dolar Amerika sebagai pendamping mata uang dalam Perjanjian Bretton Woods, setelah berakhirnya Perang Dunia II, kemudian sebagai substitusi mata uang pada awal dekade 70-an, telah mengakibatkan dolar Amerika mendominasi perekonomian global. Akibatnya, goncangan ekonomi sekecil apapun yang terjadi di Amerika pasti akan menjadi pukulan telak bagi perekonomian negaranegara lain. Sebabnya, sebagian besar-jika tidak keseluruhannyacadangan devisa mereka ditopang dengan dolar yang nilai intrinsiknya tidak sebanding dengan kertas dan tulisan yang tertera di dalamnya (nilai intrinsik tidak sebanding dengan nilai ekstrinsiknya). Setelah mata uang Euro memasuki arena pertarungan, baru negara-negara tersebut menyimpan cadangan devisanya dalam bentuk mata uang non-dolar. Meski demikian, dolar tetap memiliki prosentase terbesar dalam cadangan devisa negara-negara tersebut secara umum. Oleh karena itu, selama emas tidak menjadi cadangan mata uang, krisis ekonomi seperti ini akan terus terulang. Sekecil apapun krisis yang menimpa dolar dengan segera akan menjalar ke perekonomian negaranegara lain. Bahkan dampak krisis politik yang dirancang Amerika juga akan berakibat terhadap dolar, yang berarti juga berdampak pada dunia. $^{26}$

b) Hutang dengan menggunakan Akad Ribawi

Hutang-hutang riba juga menciptakan masalah perekomian yang besar hingga kadar hutang pokoknya menggelembung seiring dengan waktu, sesuai dengan prosentase riba yang diberlakukan padanya. Terjadinya krisis pengembalian pinjaman dan lambannya roda perekonomian adalah karena ketidakmampuan sebagian besar kelas menengah dan atas untuk mengembalikan pinjaman dan melanjutkan $\operatorname{produksi}^{27}$.

25 Zulhelmy merupakan Dosen Fakultas Ekonomi Universitas Islam Riau, di akses: http://www.detikriau.com/index.php?option=com $\operatorname{content\& task=view\& id=1558\& Itemid=86}$. Hari sabtu tanggal 7 februari 2009. Pukul 12.06 wib.

26 M. Luthfi Humaidi, Gold Dinar (Sistem Moneter Global yang Stabil dan Berkeadilan), Jakarta: Senayan Abadi Publishing, 2007, hal 101.

${ }^{27}$ Muhammad Syafi'i Antonio, Bank Syari'ah, dari Teori ke Praktek, (Jakarta: Gema Insani Press, 2002), hal 68. 
c) Sistem Bursa dan Pasar Modal

Sistem yang digunakan di bursa dan pasar modal, yaitu jual-beli saham, obligasi dan komoditi tanpa adanya syarat serah-terima komoditi yang bersangkutan - bahkan bisa diperjualbelikan berkalikali, tanpa harus mengalihkan komoditi tersebut dari tangan pemiliknya yang asli-adalah sistem yang batil dan menimbulkan masalah, bukan menyelesaikan masalah. Pasalnya, naik-turunnya transaksi terjadi tanpa proses serah-terima, bahkan tanpa adanya komoditi yang bersangkutan. Semua itu memicu terjadinya spekulasi dan goncangan di pasar. ${ }^{28}$

d) Kepemilikan yang tidak Jelas

Kepemilikan di mata para pemikir Timur dan Barat ada dua: kepemilikan umum yang dikuasai oleh negara, sebagaimana teori Sosialisme-Komunisme, dan kepemilikan pribadi yang dikuasai oleh kelompok tertentu. ${ }^{29}$ Ketidaktahuan akan fakta kepemilikan ini memang telah dan akan menyebabkan goncangan dan masalah ekonomi. Itu karena kepemilikan tersebut bukanlah sesuatu yang dikuasai oleh negara atau kelompok tertentu, melainkan ada tiga macam: (a) Kepemilikan umum: meliputi semua sumberdaya alam, baik yang padat, cair maupun gas; seperti minyak, besi, tembaga, emas dan gas; termasuk semua yang tersimpan di perut bumi dan semua bentuk energi; juga industri berat yang menjadikan energi sebagai komponen utamanya. Negara harus mengekplorasi dan mendistribusikannya kepada rakyat, baik dalam bentuk barang maupun jasa. (b) Kepemilikan negara: meliputi semua kekayaan yang diambil negara, seperti pajak dengan segala bentuknya serta perdagangan, industri dan pertanian yang diupayakan oleh negara, di luar kepemilikan umum. Semuanya ini dibiayai oleh negara sesuai dengan kepentingan negara. (c) Kepemilikan pribadi. Kepemilikan ini bisa dikelola oleh individu sesuai dengan hukum syariah. Sosialisme gagal dalam bidang ekonomi karena telah menjadikan semua kepemilikan dikuasai oleh negara. Kondisi inilah yang mengantarkan pada kehancuran. Kapitalisme juga gagal dan kini sampai pada kehancuran. Itu karena Kapitalisme telah menjadikan individu, perusahaan dan institusi berhak memiliki apa yang menjadi milik umum, seperti minyak, gas, semua bentuk energi dan industri senjata berat sampai radar. Pada saat yang sama, negara tetap berada di luar pasar dari semua kepemilikan tersebut. Hasilnya adalah goncangan

${ }^{28}$ Lihat lebih komperhensif dalam Sadono Sukirno, Pengantar Ilmu Makroekonomi, (Jakarta: Bina Grafika, 1997), hal. 247.

29 Thahir Abdul Muhsin Sulaiman, terj. Anshori Umar Sitanggal, Menanggulangi Krisis Ekonomi secara Islam, (Bandung: PT. Al- Ma'arif), hal 34 
secara beruntun dan kehancuran dengan cepat, dimulai dari pasar modal, lalu menjalar ke sektor lain, dan dari institusi keuangan menjalar ke yang lain. ${ }^{30}$ Begitulah, Sosialisme-Komunisme telah runtuh, dan kini Kapitalisme sedang atau nyaris runtuh.

Keberlanjutan persoalan dan dalamnya krisis yang tengah terjadi menunjukkan bahwa pada dasarnya ada sesuatu yang salah. Apakah kesalahan itu? Jawabannya akan banyak bergantung pada falsafah dasar kehidupan karena hal ini akan menentukan analsis kita terhadap penyebab-penyebab persoalan ini. Tak akan ada pengorbanan yang efektif kecuali hal itu diarahkan kepada arus utama krisis. Sayangnya, kesalahan yang umumnya dilakukan yaitu bahwa akar permasalahan hanya dicari pada simtom $^{31}$ (gejala-gejala) nya saja. ${ }^{32}$ Akibatnya, penyembuhan hanya bersifat sementara, seperti obat-obat analgesik, mengurangi rasa sakit hanya sementara. Beberapa saat kemudian, krisis muncul kembali, bahkan lebih mendalam dan serius lagi. Hal senada di ungkapkan oleh Michael Camdessus Direktur International Monetery Fund (IMF) dalam kata-kata sambutannya pada Growth-Oriented Adjustment Program sebagai berikut: ${ }^{33}$

"ekonomi yang mengalami inflasi yang tidak terkawal, defisit neraca pembayaran yang besar, pembatasan perdagangan yang berkelanjutan, kadar pertukaran uang yang tidak seimbang, tingkat bunga yang tidak realistik, beban hutang luar negeri yang membengkak dan pengaliran modal yang berlaku berulang kali, telah menyebabkan kesulitan ekonomi, yang akhirnya akan memerangkapkan ekonomi negara ke dalam krisis ekonomi".

Sedangkan dalam perspektif Islam, akar krisis ini terletak lebih dalam dan tidak ada upaya untuk memecahkannya hanya lewat perubahan kosmetik belaka, perlu adanya reformasi total. Targetnya adalah kesehatan sosial yang muncul dari nurani kesadaran manusia dibarengi dengan keadilan dan kejujuran di semua tingkat interaksi manusia. Kondisi kesehatan semacam ini tidak dapat dicapai tanpa adanya suatu transformasi moral individu dan masyarakat dimana ia hidup. $^{34}$

\footnotetext{
${ }^{30}$ Robert Lekachman dan Borin Van Loon, Kapitalisme (Teori dan sejarah perkembangannya), (Yogyakarta: Resist Book, 2008), hal 5.

${ }_{31}$ Adapun simtom atau gejala-gejala yang terjadi seperti: ketidakseimbangan anggaran, ekspansi moneter yang berlebihan, defisit neraca pembayaran, tidak memadainya bantuan asing dan kerjasama internasional yang tidak mencukupi

${ }^{32}$ Aam Slamet Rusdianta, dkk, hal. 46

${ }^{33}$ Indra Ismawan, Dibawah Cengkraman IMF, Peran IMF dalam Krisis Ekonomi Indonesia, (Solo: Pondok Edukasi, 2002), hal.79

${ }^{34}$ Umer Chapra, Sistem Moneter Islam, (Jakarta: Gema Insani Press, 2000), hal. XX
} 


\section{Ekonom Islam dan Krisis Ekonomi: Sebuah Pendekatan dan Analisis}

Banyak pakar yang memberikan solusi terhadap krisis ekonomi yang terjadi. Meskipun terdapat perbedaan, tetapi pada umumnya kunci dari solusi krisis adalah menghilangkan sistem bunga (riba) dalam ekonomi. Diantara mereka adalah sebagai berikut: ${ }^{35}$

1) Akram Khan dan Ariff

Akram Khan dan Ariff mengatakan bahwa untuk menstabilkan ekonomi, diperlukan empat instrumen sebagai stabilizers, yaitu: (a) sistem perbankan harus terbebas dari bunga (riba). Dimana bunga merupakan tambahan terhadap uang yang disimpan pada lembaga keuangan atau terhadap uang yang dipinjamkan. (b) pasar uang yang bebas dari spekulasi. Hal ini bertujuan agar pasar uang berada dalam keadaan seimbang secara terus-menerus antara kekayaan dalam bentuk uang dan nilai riil saham. (c) upah yang adil; upah yang adil bermakna bahwa upah yang diberikan haruslah memenuhi kriteria keadilan. Adil disini bermakna proporsional.

2) Muhammad Ramzan Akhtar

Muhammad Ramzan Akhtar mengatakan bahwa, untuk menciptakan sistem ekonomi yang benar-benar Islami, diperlukan 3 hal berikut, yaitu:

a) Menghapuskan sistem riba (interest). Basis bunga harus digantikan dengan basis bagi untung dan resiko (profit and risk sharing),

b) Perlu mendirikan institusi zakat. Zakat dapat dipakai sebagai alat ukur depresi atau booming dalam ekonomi. Zakat memiliki 3 peran: pemberantasan kemiskinan, stabilisasi dan pembangunan ekonomi.

c) Faktor moral. Dalam sistem ekonomi Islam ada 2 faktor yang diperlukan, yaitu faktor moral dan faktor material. Hal ini berbeda dengan sistem ekonomi sekuler, dimana hanya faktor materi saja yang diperhatikan.

3) Menurut Mahmud Abu Saud

Mahmud Abu Saud mengatakan bahwa, untuk menciptakan sistem ekonomi Islam sebagai solusi, diperlukan 6 pilar, yaitu:

a) Work and reward. Setiap muslim diharuskan untuk bekerja, dan dia juga harus menerima risiko apapun yang terkait dengan pekerjaan itu, tidak ada keuntungan atau manfaat yang diperoleh tanpa risiko. Inilah jiwa dari prinsip al-haraj biddhaman (dimana ada manfaat, disitu ada resiko).

35 Karnaen A. Putraatmadja dan Hendri Tanjung, Bank Syari'ah, Teori, Praktek dan Peranannya, (Jakarta: Celestial Publishing, 2007), hal. 165. 
b) No harding (menimbun uang) and monopoly. Tidak seorangpun diizinkan menimbun uang, dan uang kontan (cash) harus diusahakan. Penimbunan biasanya digunakan untuk spekulasi yang dapat berimbas pada ketidakstabilan ekonomi. Tidak ada satupun yang boleh melakukan monopoli atau oligopoli, karena Islam mendorong persaingan dalam ekonomi sebagai jiwa dari fastabiqul khairat.

c) Sepreciation. Segala sesuatu didunia ini mengalami depresiasi (penyusutan). Kekayaan juga terdepresiasi dengan zakat. Yang abadi didunia ini hanya Allah SWT.

d) Money is a just a mean of exchange. Uang hanya merupakan alat penyimpanan nilaidan uang bukanlah merupakan alat komoditi. Karena komoditi mempunyai harga, sedangkan uang tidak.

e) Interest is riba. Jumhur ulama mengatakan bahwa bunga (interest) adalah mutlak riba, yang sangat diharamkan dalam Islam. Baik itu oleh Majlis Tarjih Muhammadiyah, Organisasi Konferensi Islam (OKI), maupun oleh Mufti Negara Mesir.

f) Social solidarity. Kaum muslimin ibarat satu tubuh. Jika satu anggota tubuh sakit maka seluruh tubuh akan merasakan sakit. Jika seorang muslim mengalami problem kemiskinan, maka tugas kaum musliminlah untuk menolong orang miskin itu. Karena kekayaan adalah amanah dan titipan dari Allah SWT. ${ }^{36}$

Adapun dalam sisi perbankan ekonomi Islam telah memberikan solusi (alternatif) untuk mengindari praktek riba (bunga/interest) didalam proses perbankannya. Solusi tersebut berupa produk Mudharabah yang berbasis pada nisbah bagi hasil yang dinyatakan dalam bentuk prosentase antara shahibul mal dan mudharib, bukan dinyatakan dalam nilai nominal 'Rp' tertentu, jadi nisbah keuntungan itu misalnya adalah 50:50, 70:30 atau bahkan 99:1. ${ }^{37}$ Dengan sistem bagi hasil agaknya tidak memungkinkan bagi bank-bank komersial untuk mengajukan pinjaman yang terlalu besar sebagaimana terjadi di beberapa negara. ${ }^{38}$ Pinjaman tersebut tidak selalu berarti rahmat karena hutang kronis pinjaman bank-bank komersial kepada bank sentral sering dilihat sebagai sumber kelemahan dan menjadi cikal bakal timbulnya krisis. ${ }^{39}$ Oleh karena itu, nisbah keuntungan ditentukan berdasarkan kesepakatan, bukan berdasarkan porsi setoran

\footnotetext{
${ }^{36}$ Karnaen A. Putraatmadja dan Hendri Tanjung, Op. Cit, hal. 166.

${ }^{37}$ M. Salim, Profit Sharing vs Interest (sebuah kajian perbandingan), (Ponorogo: CIOS: 2007), hal 16.

38 Diantara negara-negara MEE, pinjaman bank-bank komersial kepada bank sentral sangat bervariasi dari satu negara dengan negara lain. Di Perancis, Belgia dan Italia, bank-bank komersial dibolehkan melakukan pinjaman dalam jumlah besarkepada bank sentral dan itu dianggap biasabiasa saja. Di Belanda, dan terlebih lagi di Inggris, pinjaman hanya dilakukan kadang-kadang saja dan biasanya hal itu dilakukan setelah tidak adala lembaga lain yang bisa memberikan pinjaman.

39 Umer Chapra, Al-Qur'a Menuju Sistem Moneter yang Adil, hal 126
} 
modal. Ketentuan ini merupakan konsekuensi logis dari karakteristik akad mudharabah itu sendiri yang tergolong kedalam kontrak investasi (natural uncertanty contrasts). Dalam kontrak ini, return dan timing cash flow nya tergantung kepada kinerja sektor riilnya. ${ }^{40}$

Berdasarkan paparan diatas, penulis sangat yakin bahwa sesungguhnya sistem ekonomi Islamlah satu-satunya solusi yang ampuh dan steril dari semua krisis ekonomi. Karena sistem ekonomi Islam benar-benar telah mencegah semua faktor yang akan menyebabkan krisis ekonomi.

Pertama: Sistem ekonomi Islam telah menetapkan bahwa emas dan perak merupakan mata uang, bukan yang lain. Mengeluarkan kertas substitusi harus ditopang dengan emas dan perak, dengan nilai yang sama dan dapat ditukar, saat ada permintaan. ${ }^{41}$ Dengan begitu, uang kertas negara manapun tidak akan bisa didominasi oleh uang negara lain. Sebaliknya, uang tersebut mempunyai nilai intrinsik yang tetap, dan tidak berubah.

Kedua: Sistem ekonomi Islam melarang riba, baik nasi'ah maupun fadhal, juga menetapkan pinjaman untuk membantu orang-orang yang membutuhkan tanpa tambahan (bunga) dari uang pokoknya. Di Baitul Mal kaum Muslim juga terdapat bagian khusus untuk pinjaman bagi mereka yang membutuhkan, termasuk para petani, sebagai bentuk bantuan untuk mereka, tanpa ada unsur riba sedikit pun di dalamnya.

Ketiga: Sistem ekonomi Islam melarang penjualan komoditi sebelum dikuasai oleh penjualnya. Karena itu, haram menjual barang yang tidak menjadi milik seseorang. Haram memindahtangankan kertas berharga, obligasi dan saham yang dihasilkan dari akad-akad yang batil. Islam juga mengharamkan semua sarana penipuan dan manipulasi yang dibolehkan oleh Kapitalisme, dengan klaim kebebasan kepemilikan.

Keempat: Sistem ekonomi Islam juga melarang individu, institusi dan perusahaan untuk memiliki apa yang menjadi kepemilikan umum, seperti minyak, tambang, energi dan listrik yang digunakan sebagai bahan bakar. Islam menjadikan negara sebagai penguasanya sesuai dengan ketentuan hukum syariah.

\section{Penutup}

Berdasarkan pemaparan diatas, dapat disimpulkan bahwa fakta empiris menunjukkan bahwa tidak ada satupun negara muslim yang berstatus negara berkembang dengan aplikasi rezim moneter konvensional yang terbilang stabil. Krisis demi krisis terus terjadi dan berulang, seperti di tahun 1930, 1970, 1997 dan 2008. Untuk mewujudkan stabilitas ekonomi ini, diperlukan beberapa langkah alternatif untuk merealisasikannya, antara lain: Pertama: Sistem ekonomi Islam

${ }^{40}$ Heri Sudarsono, Bank dan Lembaga Keuangan Syari'ah, Deskripsi dan Ilustrasi, Edisi 2, (Yogyakarta: EKONISIA, 2001), hal 21.

${ }^{41}$ Lihat lebih jelas dalam Mulia Siregar, Dinar Emas Solusi Krisis Ekonomi, (Jakarta: PIRAC SEM Institute, 2002), hal 91 
telah menetapkan bahwa emas dan perak merupakan mata uang, bukan yang lain. Kedua: Sistem ekonomi Islam melarang riba, baik nâsi'ah maupun fadhal, juga menetapkan pinjaman untuk membantu orang-orang yang membutuhkan tanpa tambahan (bunga) dari uang pokoknya. Ketiga: Sistem ekonomi Islam melarang penjualan komoditi sebelum dikuasai oleh penjualnya. Keempat: Sistem ekonomi Islam juga melarang individu, institusi dan perusahaan untuk memiliki apa yang menjadi kepemilikan umum. Kita sebagai umat Islam mengetahui bahwasanya Islam adalah agama yang tidak hanya memperhatikan kehidupan akhirat, melainkan lebih dari itu, Islam adalah agama yang kaffah dan rahmatan lil 'alamin. Mengembangkan dan memajukan ekonomi Islam adalah cita-cita kita bersama, maka dari itu kita bantu dengan semangat keIslaman, baik moril maupun materil untuk mewujudkannya. Amin ya robbal 'alamin.

\section{Daftar Pustaka}

An-Nababan, M. Faruq, 2002. Sistem Ekonomi Islam (pilihan setelah kegagalan sistem kapitalis dan sosialis), Jogjakarta: UII Press,

Antonio, Muhammad Syafi'i, 2002. Bank Syari'ah, dari Teori ke Praktek, Jakarta: Gema Insani Press,

Chapra, Umer, 1999.Islam dan Tantangan Ekonomi, Surabaya: Risalah Gusti, , 2000. Sistem Moneter Islam, Jakarta: Gema Insani Press, , 1997. Al-Qur'an Menuju Sistem Moneter yang Adil, Cet. 1, Yogyakarta: Dana Bhakti Prima Yasa,

Ismawan, Indra, Dibawah Cengkraman IMF, Peran IMF dalam Krisis Ekonomi Indonesia, Solo: Pondok Edukasi, 2002.

Izzan, Ahmad, dan Tanjung, Syahri, 2006. "Referensi Ekonomi Syari'ah (ayatayat al-qur'an yang berdimensi ekonomi), Bandung: PT. Remaja Rosdakarya,

Handry Imansyah, Muhammad, 2009. Krisis Keuangan di Indonesia Dapatkah Diramalkan?, Jakarta: PT elex Media Komputindo,

Humaidi, M. Luthfi, 2007. Gold Dinar (Sistem Moneter Global yang Stabil dan Berkeadilan), Jakarta: Senayan Abadi Publishing,

Lekachman, Robert dan Loon, Borin Van, 2008. Kapitalisme (Teori dan sejarah perkembangannya), Yogyakarta: Resist Book.

Nawawi, Ismail, Ekonomi Islam, Perspektif Teori, Sistem dan Aspek Hukum, Surabaya: CV. Putra Media Nusantara.

Pusat Pengakjian dan Pengembangan Ekonomi Islam, 2008. Ekonomi Islam, Jakarta: PT. Rajagrafindo.

Putraatmadja, Karnaen A. dan Tanjung, Hendri, 2007. Bank Syari'ah, Teori, Praktek dan peranannya, Jakarta: Celestial Publishing.

Rahman, Afzalur, 1995. Economic Doctrines in Islam terj. Doktrin Ekonomi Islam, Yogyakarta: Dana Bhakti Waqaf.

Rusdianta, Aam Slamet dkk, 2009. Ekonomi Islam Substantif, Bogor: Lembaga Penelitian dan Pemberdayaan Masyarakat (LPPM) STIE Tazkia,

Mannan, M. Abdul, 1997. Teori dan Praktek Ekonomi Islam, Yogyakarta: PT Dana Bhakti Prima Yasa. 
Salim, M, 2007. Profit Sharing Vs Interest (sebuah kajian perbandingan), CIOS: Ponorogo,

Siregar, Mulia, 2002. Dinar Emas Solusi Krisis Ekonomi, Jakarta: PIRAC SEM Institute,

Sudarsono, Heri, 2001. Bank dan Lembaga Keuangan Syari'ah, Deskripsi dan Ilustrasi, Edisi 2, EKONISIA Kampus Ekonomi UII Yogyakarta: Yogyakarta,

Sukirno, Sadono, 1997. Pengantar Ilmu Makroekonomi, Jakarta: Bina Grafik,

Sulaiman, Thahir Abdul Muhsin, yang diterjemahkan oleh Anshori Umar Sitanggal, Menanggulangi Krisis Ekonomi secara Islam, Bandung: PT. AlMa'arif. 